\title{
PENGARUH KONTROL DIRI TERHADAP HASIL BELAJAR SISWA KELAS XI SMK NEGERI 4 BATAM
}

\section{THE EFFECT OF SELF CONTROL ON STUDENT LEARNING OUTCOMES OF XI CLASS 4 STATE VOCATIONAL SCHOOL OF BATAM}

\author{
Ferawati $^{1}$, Herni Widiyah Nasrul ${ }^{2}$ \\ Program Studi Magister Manajemen Program Pascasarjana Universitas Riau Kepulauan \\ ferawati2783@gmail.com
}

\begin{abstract}
Abstrak
Sudjana (2014) menyatakan hasil belajar siswa pada hakikatnya adalah perubahan tingkah laku sebagai hasil belajar yang mencakup bidang kognitif, afektif, dan psikomotorik. Berdasarkan data hasil belajar nilai akhir semester genap pada siswa kelas XI SMK Negeri 4 Batam, siswa kelas XI belum mencapai ketuntasan pembelajaran sehingga nilai kriteria ketuntasan minimal (KKM) masih di bawah angka 75. Hal ini terlihat dari hasil pembagian rapor kelas XI pada semester genap tahun pembelajaran 2015/2016. Rendahnya hasil belajar siswa ini disebabkan oleh salah satu kurangnya kontrol diri siswa terhadap perilaku dalam pembelajaran baik di sekolah maupun di rumah. Tujuan penelitian ini adalah untuk mengetahui hubungan antara kontrol diri dengan hasil belajar siswa kelas XI SMK Negeri 4 Batam. Hasil penelitian ini dilaksanakan dengan metode kuantitatif korelasional. Adapun jumlah sampel yang di ambil 45 siswa, dengan menggunakan teknik random sampling. Metode pengumpulan data berupa angket, untuk variabel kontrol diri dan dokumentasi rapor semester genap tahun pelajaran 2015/2016. Menggunakan teknik analisis product moment korelasi SPSS version 20 for windows. Berkaitan dengan masalah yang dirumuskan untuk diteliti dan tujuan yang hendak dicapai, maka hipotesis di dalam penelitian ini, adalah sebagai berikut : Ho artinya tidak terdapat hubungan antara kontrol diri dengan hasil belajar. Ha, terdapat hubungan antara kontrol dengan hasil belajar. Dapat disimpulkan bahwa kontrol diri siswa kelas XI SMK Negeri 4 Batam. Hasil analisis data yang diperoleh pada penelitian ini dengan korelasi product moment dengan pengolahan data statistik dengan hasil korelasi rxy = 0,113 dengan taraf signifikan 0,460 > 0, 05. Hasil kesimpulan Ha ditolak dan Ho diterima artinya dinyatakan tidak terdapat hubungan yang signifikan antara kontrol diri dengan hasil belajar siswa kelas XI SMK Negeri 4 Batam.
\end{abstract}

\section{Kata kunci: Kontrol Diri, Hasil Belajar, Siswa SMK}

\begin{abstract}
Sudjana (2014) reported the results of student learning is essentially a change in behavior as a result of learning that includes the field of cognitive, affective, and psychomotor. Based on data from the final value of learning outcomes in the second semester of class XI student of SMK Negeri 4 Batam, a class XI student not achieve mastery learning so that the value of minimum completeness criteria (KKM) is still below the number 75. It is seen from the results of the division of XI grade report card on the second semester learning year 2015/2016. Low student learning outcomes is caused by a lack of self-control on the behavior of students in learning both at school and at home. The purpose of this study was to determine the relationship between selfcontrol with the learning outcomes of class XI student of SMK Negeri 4 Batam. This research was conducted by the method of quantitative correlation. The number of samples taken 45 students, using random sampling techniques. Methods of data collection in the form of questionnaires, for the variable self-control and documentation report second semester of academic year 2015/2016. Using the technique of product moment correlation analysis of SPSS version 20 for Windows. Relating to the issues to be studied and formulated objectives to be achieved, then the hypothesis in this study, is as follows: Ho means that there is no relationship between self-control with learning outcomes. Ha, there is a relationship between control and learning outcomes.It can be concluded that self-control class XI student of SMK Negeri 4 Batam. The results of analysis of data obtained in this study with the product moment correlation with statistical data processing with the results of correlation $r x y=0.113$ with significant level of $0.460>0,05$. The conclusion is rejected and Ha Ho accepted means otherwise there is no significant relationship between self-control with the result learning class XI student of SMK Negeri 4 Batam.
\end{abstract}

Keywords: Self-Control, Learning Outcomes, SMK Student 


\section{PENDAHULUAN}

Dalam Sistem Pendididikan Nasional Nomor 20 Tahun 2003, pendidikan menjadi faktor kebutuhan utama dalam pendidikan, karena bertujuan untuk mewujudkan sumber daya manusia yang berkualitas. Kualitas daya manusia dibentuk melalui guru yang berkualitas. Hal ini dikarenakan pendidikan merupakan suatu proses dalam meningkatkan, memperbaiki, mengubah pengetahuan, keterampilan serta perilaku seseorang sebagai usaha mencerdaskan manusia melalui kegiatan pengajaran dan pelatihan. Jadi kesimpulan dari hasil belajar adalah merupakan perubahan sikap dan tingkah laku manusia terhadap hasil belajarnya dan mengetahui sejauh mana siswa telah mencapai hasil yang baik dalam belajarnya.

Berdasarkan hasil penelitian sebelumnya oleh Maisaroh (2010) dengan judul "hasil belajar yang diperoleh siswa setelah mengalami proses kegiatan belajar dengan menggunakan metode pembelajaran Active Learning tipe Quiz Team. Hasil penelitian menyatakan bahwa penerapan metode pembelajaran Active Learning tipe Quiz Team, telah memberikan pengaruh yang positif terhadap peningkatan hasil belajar siswa. Nilai hasil belajar mencerminkan hasil yang dicapai seseorang dari segi kognitif, afektif, maupun psikomotorik. Menurut Wasti (2013) dalam penelitiannya yang berjudul "hubungan pemberian reward dengan hasil belajar mata pelajaran tata busana Madrasah Aliyah Negeri 2 Padang” juga melakukan penelitian kuantitatif korelasi. Hasil penelitiannya menunjukan bahwa hipotesis alternative diterima yaitu terdapat hubungan yang signifikan antara pemberi reward dengan hasil belajar. Relevansi penelitian ini adalah sama-sama meneliti tentang hasil belajar.

Berdasarkan wawancara peneliti dengan guru mata pelajaran di SMK Negeri 4 Batam, mengatakan kriteria ketuntasan minimal (KKM) di SMK Negeri 4 Batam adalah Nilai 75. Jika siswa mendapatkan total hasil nilai keseluruhan di bawah nilai angka tujuh puluh lima, maka siswa belum mengalami ketuntasan dalam pembelajaran. Ketidaktuntasan siswa dalam mata pelajaran pemrograman dasar sebanyak 45 siswa dari keseluruhan siswa pada kelas XI. tentunya dari ketidaktuntasan itu akan mempengaruhi nilai akhir semester genap. Hal tersebut diketahui dari hasil pembagian raport siswa kelas XI pada semester lalu, di SMK Negeri 4 Batam. Menurut Slameto (2010) mengemukakan bahwa faktor yang mempengaruhi hasil belajar yaitu faktor internal yang berasal dari diri individu dan faktor eksternal dari luar individu. Faktor dari dalam tersebut salah satunya adalah kontrol diri siswa terhadap pelajaran. Menurut Hamalik (2003), hasil belajar adalah sebagai terjadinya perubahaan tingkah laku pada diri seseorang yang dapat diamati dan dapat diukur bentuk 
pengetahuannya, sikap dan keterampilan. Perubahan tersebut dapat diartikan sebagai terjadinya peningkatan dan pengembangan yang lebih baik sebelumnya yang tidak tahu menjadi tahu. Menurut Ghufron (2003) menjelaskan kontrol diri berkaitan dengan bagaimana seseorang mengendalikan emosinya serta dorongan-dorongan negatif dalam dirinya kearah yang lebih positif, bermanfaat, dan dapat diterima. kearah konsekuensi positif.

Berdasarkan observasi peneliti di SMK Negeri 4 Batam pada tanggal 18 Agustus 2015 sampai dengan 05 Desember 2015. Adapun yang menjadi permasalahan dalam penlitian ini adalah: Masalah kontrol diri siswa dengan hasil belajar. Siswa belum mampu menghadapi lingkungan kelas dengan baik seperti ketika guru tidak masuk kelas. Siswa membuat keributan didalam kelas, sehingga tugas yang diberikan tidak diterima dengan baik. Mudah tersinggung dengan ejekan teman sehingga mengakibatkan perkelahian. Siswa tidak memikirkan konsekuensi atas apa yang mereka lakukan seperti membentak teman ketika siswa memiliki masalah pribadi. Ketika guru lambat masuk kelas, siswa membuat keributan di dalam kelas. Siswa lebih mengutamakan pergi bermain dengan teman-teman dibandingkan mengerjakan tugas yang membuat mereka stress. Pengontrolan diri siswa tentunya berkaitan dengan hasil belajar. Siswa yang belum mampu mengontrol dirinya akan menghambat informasi yang ditransfer pada siswa, Sehingga hal tersebut mempengaruhi hasil belajar siswa.

\section{Hasil Belajar}

Menurut Purwanto (2014) juga mengatakan hasil belajar dapat dijelaskan dengan memahami dua kata yang membentuknya, yaitu "hasil" dan "belajar". Pengertian hasil (product) menunjukan pada suatu perolehan akibat dilakukannya suatu aktifitas atau proses yang mengakibatkan berubahnya input secara fungsional. Sedangkan belajar dilakukan untuk mengusahakan adanya perubahan perilaku pada individu yang belajar. Perubahan perilaku itu merupakan perolehan yang menjadi hasil belajar, selain hasil belajar kognitif yang diperoleh peserta didik.

1. Faktor-faktor yang mempengaruhi hasil belajar.

Menurut Slameto (2010) mengatakan bahwa setiap kegiatan belajar menghasilkan suatu perubahan yang khas sebagai hasil. Hasil belajar dapat dicapai peserta didik melalui usaha-usaha sebagai perubahan tingkah laku yang meliputi ranah kognitif, afektif dan psikomotorik, sehingga tujuan yang telah ditetapkan tercapai secara optimal. Hasil belajar 
yang diperoleh peserta didik tidak sama karena adanya beberapa faktor yang mempengaruhi keberhasilanya dalam proses belajar.

3. Aspek Hasil Belajar

Dimyati (2012) hasil belajar dapat dikatakan berhasil apabila telah mencapai tujuan pendidikan. Dimana tujuan pendidikan berdasarkan hasil belajar peserta didik secara umum dapat diklarifikasikan menjadi tiga yakni : kognitif, afektif dan psokomotorik.

\section{Kontrol Diri}

Menurut Chaplin (1997) kontrol diri seringkali diartikan sebagai kemampuan untuk menyusun, membimbing, mengatur dan mengarahkan bentuk perilaku yang dapat membawa kea rah konsekuensi positif. Kontrol diri juga merupakan salah satu potensi yang dapat dikembangkan dan digunakan individu selama proses-proses dalam kehidupan, termasuk dalam menghadapi kondisi yang terdapat di lingkungan yang berada disekitarnya. Para ahli berpendapat bahwa kontrol diri dapat digunakan sebagai suatu intervensi yang berssifat preventif selain dapat mereduksi efek-efek psikologis yang negative dari stressor-stressor lingkungan.

Pengertian Kontrol Diri

1) Kemampuan mengontrol stimulus

Kemampuan untuk mengetahui bagaimana dan kapan suatu stimulus yang tidak dikehendaki muncul. Ada beberapa cara yang dapat digunakan yaitu mencegah atau menjauhi stimulus, mengehntikan stimulus sebelum berakhir, dan melakukan kegiatan yang dapat mengalihkan perhatian dari stimulus.

2) Kemampuan mengantisipasi peristiwa

Kemampuan individu dalam mengolah informasi dengan cara menginterprestasi, menilai atau menggabungkan suatu kejadian dalam suatu kerangka kognitif. Informasi yang dimiliki individu mengenai suatu keadaan yang tidak menyenangkan akan membuat individu mampu mengantisipasi keadaan melalui pertimbangan secara objektif.

4) Kemampuan menafsirkan peristiwa

Penilaian yang dilakukan seorang individu merupakan suatu usaha untuk menilai dan menafsirkan suatu keadaan dengan memperhatikan segi-segi positif secara subjektif.

1) Kemampuan mengambil keputusan

Kemampuan seseorang untuk memilih suatu tindakan berdasarkan sesuatu yang diyakini atau disetujuinya. Kemampuan dalam mengontrol keputusan akan berfungsi dengan baik apabila 
terdapat kesempatan dan kebebasan dalam diri individu untuk memilih berbagai kemungkinan.

\section{Hipotesis Penelitian}

Hipotesis adalah jawaban sementara terhadap rumusan masalah penelitian yang diajukan. Menurut Sugiyono (2013). Hipotesis merupakan pernyataan yang bersifat tekaan dari hubungan antara dua atau lebih variabel. Berkaitan dengan masalah yang dirumuskan untuk diteliti dan tujuan yang hendak dicapai, maka hipotesis di dalam penelitian ini, adalah sebagai berikut:

Ho: Tidak terdapat hubungan antara kontrol diri dengan hasil belajar siswa.

Ha: Terdapat hubungan antara kontrol diri dengan hasil belajar siswa.

\section{METODOLOGI}

\section{Jenis Penelitian}

Sugiyono (2013) Metode penelitian merupakan cara ilmiah untuk mendapatkan data dengan tujuan dan kegunaan tertentu. Dalam sebuah penelitian, hal yang perlu diperhatikan bagi seorang peneliti adalah ketetapan penggunaan metode yang harus disesuaikan dengan masalah dan tujuan penelitian yang ingin dicapai, sehingga penelitian dapat mengarah dan berjalan dengan baik dan sistematis.

\section{Identifikasi Variabel Penelitian}

Menurut Sugiyono (2010) variabel penelitian adalah suatu atribut atau sifat dan nilai dari orang, objek atau kejadian yang mempunyai variasi tertentu yang ditetapkan oleh penelitian untuk dipelajari dan kemudian ditarik kesimpulanya. Menurut hubungan antara satu variabel dengan variabel yang lain maka macam-macam variabel dalam penelitian dapat dibedakan menjadi dua yaitu:

1. Variabel Independen

Variabel independen: variabel ini sering disebut sebagai variabel stimulus, prediktor, antecedent. Dalam Bahasa Indonesia sering disebut sebagai variabel bebas. Variabel bebas adalah merupakan variabel yang mempengaruhi atau yang menjadi sebab perubahannya atau timbulnya variabel dependen (terikat). Dalam penelitian ini variabel independen (X) adalah kontrol diri

2. Variabel Dependen

Variabel Dependen: sering sebagai variabel out put, kriteria, konsenkuen. Dalam bahasa Indonesia sering disebut sebagai variabel terikat. Variable terikat merupakan variabel yang 
dipengaruhi atau menjadi akibat, karena adanya variabel bebas. Dalam penelitian ini variabel dependen (Y) adalah hasil belajar.

\section{Populasi dan Sampel Penelitian}

1. Populasi

Sugiyono (2013) mengatakan bahwa populasi adalah wilayah generalisasi yang terdiri atas: obyek/subyek yang mempunyai kualitas dan karakteristik tertentu yang ditetapkan oleh peneliti untuk dipelajari dan kemudian ditarik kesimpulannya. Populasi pada penelitian ini yaitu seluruh siswa kelas XI SMK Negeri 4 Batam adalah 270 siswa.

Tabel. 1. Populasi Siswa Kelas XI SMK Negeri 4 Batam

\begin{tabular}{ccc}
\hline Kelas & Jurusan & Jumlah siswa \\
\hline X & RPL-1 & 30 siswa \\
X & RPL-2 & 30 siswa \\
X & RPL-3 & 30 siswa \\
X & RPL-4 & 30 siswa \\
X & RPL-5 & 30 siswa \\
X & MM-1 & 30 siswa \\
X & MM-2 & 30 siswa \\
X & KI-1 & 30 siswa \\
X & KI-2 & 30 siswa \\
Jumlah & & 270 siswa \\
\hline
\end{tabular}

Sumber: SMKN 4 Batam, 2015

\section{Tahapan Prosedur Penelitian}

Dalam pelaksanaan penelitian ini, peneliti menempuh beberapa langkah sebagai berikut:

1. Tahap persiapan

Sebelum penelitian dilaksanakan, maka peneliti melakukan persiapan terlebih dahulu. Adapun langkah-langkah yang dipersiapkan oleh peneliti untuk persiapannya yaitu:
a. Menentukan tempat penelitian
b. Bimbingan angket
c. Penetapan jadwal dan waktu penelitian
d. Mempersiapkan angket penelitian
e. Melaksanakan penelitian 
2. Tahap Pengambilan Subyek.

Dalam memilih dan menentukan subyek penelitian untuk kelas XI SMK Negeri 4 Batam, disini peneliti menggunakan teknik pengambilan probability sampling dengan menggunakan metode simple random sampling yaitu penentuan sampel dengan pertimbangan tertentu.

3. Tahap Pelaksanaan

\section{Uji Validitas}

Sugiyono (2013) Validitas merupakan suatu ukuran yang menunjukkan tingkat kevalidan atau kesahihan suatu instrument. Suatu instrument dikatakan valid jika instrumen yang digunakan dapat mengukur apa yang seharusnya diukur. Hasil penelitian yang valid terdapat kesamaan antara data yang terkumpul dengan data yang sesungguhnya terjadi pada obyek yang diteliti. Suatu instrumen yang valid atau yang sahih mempunyai validitas tinggi, sebaliknya instrumen yang kurang valid berarti memiliki validitas rendah.

Dalam penentuan tingkat validitas soal dalam penelitian ini digunakan rumus Product moment Correlation menggunakan program SPSS 20. Selanjutnya keluaran hasil hasil SPSS 20 akan diperoleh keofisien korelasi masing-masing item. Menurut Sogiyono (2013) dinyatakan valid apabila jumlah $r>0,3$ atau minimal $r$ adalah 0,3.

\section{Uji Reliabilitas}

Menurut Sugiyono (2010) Reliabilitas adalah ukuran ketetapan alat penelitian dalam mengukur sesuatu yang diukur. Suatu tes dikatakan mempunyai taraf kepercayaan yang tinggi tes tersebut dapat memberikan hasil yang tepat atau seandainya hasil berubah-rubah. Perubahan yang terjadi dapat dikatakan tidak berarti.

Tabel 6 Kategorisasi Reliabilitas

\begin{tabular}{cc}
\hline Batasan & Katagori \\
$0,80 \leq \mathrm{r} \leq 1,00$ & Reliabilitas sangat tinggi \\
$0,60 \leq \mathrm{r} \leq 0,80$ & Reliabilitas tinggi \\
$0,40 \leq r \leq 0,60$ & Reliabilitas sedang \\
$0,20 \leq r \leq 0,40$ & Reliabilitas rendah \\
$0,00 \leq r \leq 0,20$ & Reliabilitas sangat rendah \\
\hline
\end{tabular}


Tabel 7 Hasil Perhitungan Reliabilitas Kontrol Diri

Reliability Statistics

\begin{tabular}{lrrr}
\hline Cronbach's Alpha & \multicolumn{2}{l}{ N of Items } \\
\hline & .943 & 31 \\
\hline
\end{tabular}

Berdasarkan Tabel 6 uji angket kontrol diri di atas dengan menggunakan koefisien Alpha Cronbach's memiliki nilai sebesar 0,943, maka intrumens angket kontrol diri reliable dengan $\mathrm{p}>0,5$ dan mempunyai koefisien yang sangat tinggi karena berada pada interval koefisien $0,80-1,00$.

\section{Teknik Analisis Data}

Analisis data bertujuan untuk menjawab pertanyaan penelitian dan menguji hepotisis yang diajukan diterima atau ditolak. Berdasarkan rancangan penelitian, maka analisis data dilakukan dengan menggunakan teknik statistik korelasi Product Moment Correlation SPSS version 20 kolmogorov Smirnov. Sebelum peneliti melakukan analisis data peneliti terlebih dahulu peniliti melakukan uji asumsi yaitu, uji normalitas dan uji linieritas.

Tabel 12 Hasil Perhitungan Uji Linieritas Kontrol Diri dengan Hasil Belajar

\begin{tabular}{|c|c|c|c|c|c|c|c|}
\hline & & & $\begin{array}{l}\text { Sum of } \\
\text { Squares }\end{array}$ & $\mathrm{df}$ & $\begin{array}{l}\text { Mean } \\
\text { Square }\end{array}$ & $\mathrm{F}$ & Sig. \\
\hline \multirow{6}{*}{$\mathrm{X} * \mathrm{Y}$} & \multirow{4}{*}{$\begin{array}{l}\text { Between } \\
\text { Groups }\end{array}$} & (Combined) & 12614.367 & 35 & 360.410 & 1.104 & .469 \\
\hline & & Linearity & 198.783 & 1 & 198.783 & 609 & .455 \\
\hline & & $\begin{array}{l}\text { Deviation } \\
\text { from }\end{array}$ & 12415.583 & 34 & 365.164 & 1.118 & .459 \\
\hline & & Linearity & & & & & \\
\hline & \multicolumn{2}{|c|}{ Within Groups } & 2938.833 & 9 & 326.537 & & \\
\hline & \multicolumn{2}{|l|}{ Total } & 15553.200 & 44 & & & \\
\hline
\end{tabular}

Sumber: Hasil Pengolahan Data, 2015

Berdasarkan uji linieritas di atas dapat dijelaskan bahwa nilai $\mathrm{F}=1,118$ dengan sig $=459>$ 0,005 yaitu. Dengan demikan maka dikatakan data sudah linier.

Uji Hipotesis 
Model korelasi dikatakan layak apabila signifikan pada hasil perhitungan statistik adalah < 0,05. Berdasarkan hasil dari perhitungan SPSS Statistics Version 20 For Windows, maka dapat dilihat dalam tabel hasil perhitungan di bawah ini :

Tabel 13 Korelasi Antara Kontrol Diri dengan Hasil Belajar

Correlations

\begin{tabular}{rlrr}
\hline & & & \\
\hline & Pearson Correlation & 1 & .113 \\
$\mathrm{X} \quad$ Sig. (2-tailed) & & .460 \\
& $\mathrm{~N}$ & 45 & 45 \\
& Pearson Correlation & .113 & 1 \\
$\mathrm{Y} \quad$ Sig. (2-tailed) & .460 & \\
& N & 45 & 45 \\
\hline
\end{tabular}

Berdasarkan perhitungan dengan menggunakan bantuan SPSS Statistic Version 20 for windows, maka didapatkan hasil dari hubungan (korelasi) rxy $=0,113$, bahwa Ho ditolak karena nilai signifikasi hasil korelasi menunjukkan angka probabilitas $0,460>0,05$. Artinya tidak terdapat hubungan yang signifikan antara kontrol diri dengan hasil belajar siswa.

\section{KESIMPULAN DAN SARAN}

\section{Kesimpulan}

Dapat disimpulkan bahwa kontrol diri siswa kelas XI SMK Negeri 4 Batam. Tergolong tinggi. Hasil analisis data yang diperoleh pada penelitian ini dengan korelasi product moment dengan pengolahan data statistic dengan hasil correlation rxy $=0,113$ dengan taraf signifikan 0,460 > 0, 05. Hasil kesimpulan Ha ditolak dan Ho diterima artinya dinyatakan tidak terdapat hubungan yang signifikan antara kontrol diri dengan hasil belajar siswa kelas XI SMK Negeri 4 Batam. Kontrol diri tidak hanya dipengaruhi oleh hasil belajar saja tetapi bisa jadi dipengaruhi oleh faktor lain.

\section{Saran}

Berdasarkan hasil penelitian yang ditemukan dalam penelitian ini maka peneliti dapat menarik beberapa saran dalam upaya meningkatkan pengetahuan untuk mencari faktor-faktor lain yang mempengaruhi nilai prosedur kriteria ketuntasan minimal guna meningkatkan hasil belajar siswa yang lebih baik lagi. 
1. Bagi Guru

Sebagai bahan masukan dalam informasi bagi pihak guru dan sekolah, bahwa kontrol diri sangat berperan penting bagi siswa untuk mencapai hasil belajar yang bagus dalam semua mata pelajaran.

2. Bagi Siswa

Penelitian ini, dapat diharapkan sebagai pembelajaran dan sebagai pembekalan menambah wawasan, ilmu pengetahuan agar mendapatkan hasil belajar secara optimal.

3. Bagi Lembaga/ Sekolah

Sebagai bahan masukan dan menambah ilmu wawasan, tentang kontrol diri terhadapa hasil belajar siswa.

4. Bagi Peneliti selajutnya

Dapat dijadikan acuan penelitian dan referensi bagi peneliti selanjutnya dalam melakukan penelitian.

\section{REFERENSI}

Arikunto. 2010. Prosedur Penelitian Suatu. Pendekatan Praktik. Jakarta: Rineka Cipta.

A Muri Yusuf. 2005. Metode Penelitian Kunatitatif. Kualitatif dan Gabungan.

Anggia Meytasari. (2013). Kontribusi Kontrol Diri Terhadap Kedisiplinan Siswa Di Sekolah Dan Implikasinya Bagi Program Bimbingan Dan Konseling. Universitas Pendidikan Indonesia. Repository. Upi.edu.

Averill, J.R. 1973. Pyschcological Bullentin. Personal Control Over Aversis Stimuli and It's Relationship to Stress.

Chaplin, J.P. 2002. Kamus Lengkap Psikologi. Raja Grafindo Persada. Jakarta

Calhoun, J.R. \& Acocella, J.R. 1990. Pshycology of Adjusment and Human Relationship. New York: Mc.Gow. Hill.Inc.

Chaplin, J.P. 1997. Kamus Lengkap Psikologi. Raja Grafindo Persada. Jakarta

Depdiknas. 2011. Undang -undang RI Nomor 20, Tahun 2003 dan Penjelasannya Jakarta:SL Media

Dimyati. 2012. Belajar dan Pembelajaran. Jakarta: Yuspika 
Elfida, D. 1995. Hubungan Kemampuan Mengontrol Diri dan Kecenderungan Berprilaku Delikuen Pada Remaja. Skripsi (tidak diterbitkan). Fakultas Psikologi: Universitas Gadjah Mada Yogyakarta.

Gunawan. 2013. Belajar dan Pembelajaran . Jakarta: Prama Publishing

Ghufron, M. Nur, dan Rini R. S. 2010. Teori-teori Psikologi. Jogjakarta: Ar-ruzz media.

Ghozali .2011. Aplikasi Analisis Multivariate dengan Program SPSS: Semarang. Universitas Diponegoro.

Hurlock, E, B. 1990. Psikologi Perkembangan. Jakarta: Erlangga

Hurlock, E, B. 1991. Enclyopedia of Education Research ( $3^{\text {rd }}$ ed). New York: The Mac Millan. Company.

Hartono. 2014. Pendekatan Model Pembelajaran Berbasis Aktivitas Untuk Meningkatkan Motivasi belajar Aqidah Akhlak Siswa Kelas XI Semester Ganjil Madrasah Aliyah Wali Songo Pucanganom Kebunsari Madiun, Jurnal Ilmiah Pendididkan. Vol 02, 97105 ISSN : 2354-5968

Jazuli.A.S. 2008. "Perilaku Seksual Remaja Ditinjau dari Kontrol Diri dan Pengetahuan Seksualitas dalam Materi Figh di Pondok Pesantren Pelajar.: Universitas Muhammadiyah. Surakarta.

Jihad. A. 2012. Evaluasi Pembelajaran. Yogyakarta: Multi Pressindo.

Lazarus, R, S. 1991. Pattern of Adjusment. Third Edition. Tokyo: McGraw Hil. Koga Kusha, LTD.

Maisaroh, dan Rostrieningsih. 2010. Peningkatan Hasil Belajar Siswa dengan Menggunakan Metode Pembelajaran Active Learning Tipe Quiz Team pada Mata Pelajaran Keterampilan Dasar Komunikasi di SMK Negeri 1 Bogor. Vol 8 (2), 16 halaman. Tersedia:

Journal.uny.ac.id/index.php/jep/article/viewFile/571/427/25/Mei/2014.

Musfiqon. 2012. Perkembangan Media dan Sumber Pembelajaran. Jakarta: Prestasi Pustaka.

Muhid, A. 2009. "Hubungan Antara Self-Control dan Self-Efficacy Dengan Kecendurang Perilaku Prokrastinasi Akademik Mahasiswa. Fakultas Dakwah IAIN Sunan Ampel Surabaya”. Surabaya: Gunadarma.

Muhibbin S. 2010. Psikologi Pendidikan dengan Pendekatan Baru. Bandung: Remaja Rosdakarya.

Oemar, Hamalik. 2003. Proses Belajar Mengajar. Jakarta: PT. Bumi Aksara. 
Pendidikan Nasional. Jakarta: Sekretariatan Jenderal Departement Pendidikan Nasional.

Purwanto. 2008. Evaluasi Hasil Belajar. Yogyakarta: Pustaka Pelajar.

Purwanto. 2014. Evaluasi Hasil Belajar. Yogyakarta: Pustaka Pelajar

Prayitno. 2009. Wawasan Prosfesional Konseling. UNP

Raodlah. E.F. 2009. "Hubungan Pembinaan dan Kecerdasan Emosi dengan Kontrol Diri Narapidan Lembaga Pemasyarakatan Klas II B Pasuruan”. Fakultas Ilmu Pendidikan: Universitas Negeri Malang.

Rahayu Dyah. D. W.. 2009. "Hubungan Signifikan Antara Kontrol Diri dengan Kecanduan Internet Pada Siswa Sekolah Menengah Pertama (SMP): Universitas Muhamadiyah. Surakarta.

Sudjana. N. 2014. Penilaian Hasil Proses Belajar Mengajar. Bandung: Rosdakarya

Santrock, J. W. 2003. Perkembangan Remaja. Jakarta: Erlangga.

Smet. B. 1994. Psikologi Kesehatan. Jakarta: PT. Grasindo.

Slameto. 2010. Belajar dan Faktor-Faktor Yang Mempengaruhinya. Jakarta: Rineka cipta.

Santrock. 2007 Psikologi Pendidikan Tri Wibowo. B.S: Jakarta kencana

Sugiyono. 2013. Metode Kuantitatif-Kualitatif dan R\&D. Bandung: Alfabeta

Sugiyono. 2013. Statistik Untuk Penelitian. Bandung: Alfabeta.

Sugiyono. 2013. Metode Penelitian Kuantitatif Kualitatif dan R\&D, Bandung: Alfabeta,cv

Sugiyono. 2013. Statistik Nonparametris, Bandung Alfabeta,cv

Sundayana, H.R 2014, Statistika Penelitian Pendidikan, Bandung: CV. Alfabeta

Sudariyanto. 2014. Meningkatkan Hasil Belajar dan Aktivitas Belajar tentang Kenampakna Buatan di Wilayah Indonesia dengan Media Visual pada Siswa Kelas V SDN Selodakon 04 Kecamatan Tanggul Kabupaten Jember Tahun Pelajaran 2013/2014. Jurnal, 3,187-198.

Sagita. S 2010. Hubungan Antara Kontrol Diri Dalam Sikap Belajar Matematika Terhadap Hasil Belajar Matematika.” Skripsi, tidak diterbitkan, Universitas Muhamadiyah Pekanbaru Riau.

Usman. 2001. Evaluasi Pembelajaran. Jakarta: Jakarta Multi Pressindo

Undang-undang Republik Indonesia Nomor 20 Tahun 2003 tentang Sistem

Wasti, S. 2013. Hubungan Pemberian Reward dengan Hasil Pelajaran Tata Busana di Madrasah Aliyah Negeri 2 Padang. Jurnal,tidak diterbitkan. 
Wika, Budiarti,S. 2015. “Hubungan Antara Perhatian Orang Tua Dengan Minat Belajar Siswa Kelas VIII Di SMP Negeri 3 Batam”, skripsi tidak diterbitkan, Universitas Riau Kepulauan, Batam

Widiana dkk. 2004 Skripsi Psikologi Indonesia. 2004 Hubungan Kontrol (self kontrol) dengan JUVENILE DELINQUENSCY pada pelajar SMAN 1 Sooko kabupaten Mojokerto.

Yuniar Rachdianti. 2011. Fakultas Psikologi Regular Universitas Islam Negeri Syarif Hidayahtulloh: Jakarta.2011

Yulistianingsi. 2015. “Hubungan Antara Konsep Diri Dengan Penyesuaian Diri Siswa Di SMP Swasta Kartini 1 Batam”. Skripsi tidak diterbitkan, Universitas Riau Kepulauan, Batam 